\title{
Sacrifice Ratio and Cost of Inflation for the Indian Economy
}

\author{
Ravindra H. Dholakia
}

W.P. No. 2014-02-04

February 2014

The main objective of the working paper series of the IIMA is to help faculty members, research staff and doctoral students to speedily share their research findings with professional colleagues and to test out their research findings at the pre-publication stage.

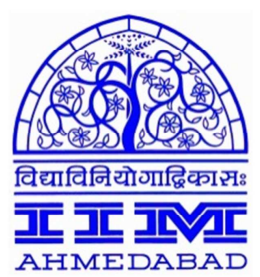

INDIAN INSTITUTE OF MANAGEMENT

AHMEDABAD-380 015

INDIA 


\title{
Sacrifice Ratio and Cost of Inflation for the Indian Economy
}

Ravindra H. Dholakia

IIM Ahmedabad

E-mail : rdholkia@iimahd.ernet.in

\begin{abstract}
Traditional concept of the Sacrifice Ratio measures the loss of potential output sustained by the society in the medium term to achieve reduction in the long-run inflation by one percentage point. This concept is critically examined and generalized to include episodes increasing the long-run inflation rate to gain higher growth of output and employment and hence reduction in the poverty proportion in the medium term. Since the concept needs measurement through a shifting short-run equilibrium of dynamic aggregate demand and supply in terms of inflation rate and output attributable to monetary policy interventions, its estimation is challenging. There are two alternative approaches to estimate the ratio, the direct one and regression based. Both have their relative merits and demerits. The regression based approach provides one unique average estimate of the Sacrifice Ratio for all episodes but allows holding other factors constant. The direct approach provides separate estimates by episodes but fails to hold other factors constant. The Sacrifice Ratio turns out to be in a narrow range of 1.8 to 2.1 for deliberate deflation and 2.8 for inflation in India. On the other hand, benefits of one percentage point reduction in trend rate of inflation are at best 0.5 percentage points increase in long-term growth of output that occurs after 4-5 years. This has implications on policy to disinflate.
\end{abstract}

\section{Introduction}

Sacrifice Ratio essentially represents the cost of permanently reducing inflation in terms of possible loss of output. It is, therefore, a very relevant concept for the policy makers, but its empirical estimation involves practical difficulties that make it less reliable for direct application. As such, there are only two serious efforts to estimate the Sacrifice Ratio for the Indian economy (RBI, 2002; and Kapur \& Patra, 2003). RBI (2002) reports only one estimate of +2 for the

\footnotetext{
${ }^{1}$ Data collection and computational assistance provided by Mr. Shrikant Taparia is gratefully acknowledged.
} 
Sacrifice Ratio for India. On the other hand, Kapur \& Patra (2003) have shown that the estimates of the Sacrifice Ratio for the Indian economy differ widely depending on: (a) measure of inflation- whether WPI based or GDP deflator based; (b) time period considered; and (c) alternative specifications of the short-run aggregate supply equation. Their estimates vary from 0.3 to 4.7 and in some of the cases the estimates were not statistically significantly different from zero. Such a wide range of estimates of the ratio is also a feature of the empirical studies for various other countries like USA, Canada, Australia, New Zealand and OECD countries (see Kapur \& Patra, 2003 for summary with references).

Thus, there is a need to examine the precise concept of the Sacrifice Ratio and methods to estimate it, particularly for a fast growing economy like India. The present paper discusses the concept of the Sacrifice Ratio within the standard macroeconomic theory and considers some of its features not emphasized in the literature in the next section. The third section critically reviews various methods to estimate it. It also presents the estimates of the ratio for the Indian Economy by appropriate methods in the fourth section. The fifth section discusses the cost of inflating or the benefits of disinflating in the long-run in the Indian context and the last section provides concluding remarks with some policy implications.

\section{Concept of the Sacrifice Ratio}

Standard textbooks define the Sacrifice Ratio as percentage of a year's real output lost in order to obtain 1 percentage point reduction in the inflation rate (see Mankiw, 2010, p.396 and Dornbusch, Fischer \& Startz, 2012, p.147). Whatever empirical evidence exists on various economies suggests that efforts to reduce inflation on permanent basis invariably involve some cost in terms of the temporarily increased unemployment and lower output over medium term.

The literature considers the Sacrifice Ratio only when there is a deliberate effort by the monetary authority to reduce the inflation rate permanently; and not when the unemployment is reduced by deliberate policy below its natural rate. The latter would also involve a similar sacrifice of living with higher inflation permanently to reduce unemployment and pull people above the poverty line through temporary cumulative income gains. For a developing country 
like India where a large proportion of population lives in poverty, this could be a legitimate policy option for poverty reduction. This is particularly relevant in the light of the argument by Fischer (1993) and Barro (1995) that inflation rate of 10 percent or less may not have any adverse impact on growth. Thus, if the trend rate of inflation is $8 \%$ in India and if RBI wants to bring it down to $5 \%$, according to Fischer (1993) and Barro (1995), resultant gain in the long term growth in the economy may not be sufficient to justify any sacrifice of consequent output loss. The same argument would also justify increasing the trend rate of inflation from $5 \%$ to $8 \%$ because of the resultant employment and output gain in the interim period to achieve poverty reduction.

Therefore, in the case of India, it is necessary to examine the validity of the arguments of Fischer (1993) and Barro (1995), i.e. whether or not reduction in the trend rate of inflation from moderate level to lower level entails any benefits in terms of higher long term growth; and whether or not increase in the average inflation rate from lower to moderate level leads to lower long term growth. If these arguments are valid, we may consider defining the Sacrifice Ratio for the Indian economy in terms of inflation cost of reducing unemployment and poverty temporarily.

The standard dynamic general equilibrium model provides better insights into the concept of Sacrifice Ratio. The concept is relevant in a dynamic model and not in the static model of Aggregate Demand (AD) and Aggregate Supply (AS). Dynamic Stochastic General Equilibrium (DSGE) models would address the issue. At the basis of such models lies a simplified framework consisting of Dynamic Aggregate Demand (DAD) and Dynamic Aggregate Supply (DAS) functions. In AD \& AS, we have a relationship between Price level (P) and Output (Y), whereas in DAD and DAS, the relationship is between inflation rate $(\pi)$ and output $(\mathrm{Y})$. In order to get clarity about other variables entering the DAD and DAS functions, we briefly derive them here in the most simplified open economy framework. In the standard notations, the model is as follows:

$\mathrm{C}=\mathrm{C}^{*}+\mathrm{c}(\mathrm{Y}-\mathrm{T}) \quad \Rightarrow$ Consumption Function;

$\mathrm{I}=\mathrm{I}^{*}-\mathrm{br}=\mathrm{I}^{*}-\mathrm{bi}+\mathrm{b} \pi^{\mathrm{e}} \Rightarrow$ Investment Function; 
$\mathrm{r}=\mathrm{i}-\pi^{\mathrm{e}} \quad \Rightarrow \mathrm{r}$ is real interest, $\mathrm{i}$ is nominal interest and $\pi^{\mathrm{e}}$ is expected inflation;

$\mathrm{NX}=\mathrm{NX}^{*}+\mathrm{j}\left(\mathrm{eP}_{\mathrm{f}} / \mathrm{P}\right)-\mathrm{mY}=>$ Net Export Function, where $\mathrm{e}$ is nominal exchange rate, $\mathrm{P}_{\mathrm{f}}$ is foreign price level, and $\mathrm{P}$ is domestic price level.

$\mathrm{G}^{*}$ is Government final expenditure;

All variables with '*' represent autonomous demand;

$\mathrm{L}=\mathrm{M}_{\mathrm{D}} / \mathrm{P}=\mathrm{kY}-\mathrm{hi} \quad \Rightarrow$ Money Demand Function

$\mathrm{M}=\mathrm{M}_{\mathrm{S}} / \mathrm{P} \quad$ => Money Supply

Therefore, the money market equilibrium is given by -

$\mathrm{i}=(\mathrm{k} / \mathrm{h}) \mathrm{Y}-(\mathrm{i} / \mathrm{h})(\mathrm{Ms} * / \mathrm{P}) \quad \Rightarrow$ LM curve

And the goods \& services market equilibrium is given by -

$\mathrm{Y}=\mathrm{A}^{*} \propto-\mathrm{b} \propto . \mathrm{i}+\mathrm{b} \propto . \pi^{\mathrm{e}}+\mathrm{bj} \propto(\mathrm{eP} / \mathrm{P}) \Rightarrow$ IS curve and $\mathrm{A}^{*}$ is all autonomous expenditures or demand

Where $\quad \propto=1 / 1-\mathrm{c}+\mathrm{m} \quad \Rightarrow$ simple open economy Keynesian multiplier.

Solving IS \& LM together and taking $\quad \beta=\left(\frac{\propto}{h+\propto b k}\right), \quad$ we get,

$\mathrm{Y}=\mathrm{h} \beta \mathrm{A}^{*}+\mathrm{b} \beta\left(\mathrm{M}_{\mathrm{S}} * / \mathrm{P}\right)+\mathrm{hb} \beta \pi^{\mathrm{e}}+\mathrm{hj} \beta\left(\mathrm{eP}_{\mathrm{f}} / \mathrm{P}\right)$

Taking first difference in the above equation, we get,

$\mathrm{Y}=\mathrm{Y}_{-1}+\mathrm{h} \beta\left(\Delta \mathrm{A}^{*}\right)+\mathrm{b} \beta(\mathrm{Ms} * / \mathrm{P})\left(\mathrm{g}_{\mathrm{Ms}}-\pi\right)+\mathrm{hb} \beta\left(\Delta \pi^{\mathrm{e}}\right)+\mathrm{hj} \beta\left(\mathrm{eP}_{\mathrm{f}} / \mathrm{P}\right)\left(\mathrm{g}_{\mathrm{e}}+\pi_{\mathrm{f}}-\pi\right) \Rightarrow \mathrm{DAD}$

Function $^{2}$

Turning to the Dynamic Aggregate Supply (DAS), it has the following three component functions: production function, wage-price relationship for setting prices, and extended expectation augmented Phillips curve. In the short run, the production is assumed to be proportional to labour, which is the same thing as assuming constant average labour productivity. The price fixation is assumed to be on the basis of mark-up pricing on variable costs, of which the wage bill is a major component. The extended augmented Phillips curve as discussed in Dornbusch and Fischer (1990, p.581-82) and Dholakia and Sapre (2011) makes the growth in wages a function of expected inflation $\left(\pi^{\mathrm{e}}\right)$, unemployment rate difference from its natural rate,

\footnotetext{
${ }^{2}$ The derivation given here is an extended version of Dornsbusch and Fischer (1990), Appendix to Ch.14. There are other ways to derive the DAD function also. One alternative is to treat the nominal interest (i) as a policy variable depending on the Talyor's rule. For details, see Mankiw (2010). Since there is no conclusive evidence that RBI follows interest rate policy based on Taylor's rule, we prefer the derivation given in the text above.
} 
and changes in unemployment rate from the past. Based on these three component functions and the definition of the unemployment rate, Dholakia \& Sapre (2011) derive the equation of the DAS as

$$
\pi=\pi^{\mathrm{e}}+\in\left[\left(\mathrm{Y}-\mathrm{Y}^{*}\right) / \mathrm{Y}^{*}\right]+(\mathrm{n} / \mathrm{q})\left(\mathrm{g}_{\mathrm{Y}}-\mathrm{g}_{\mathrm{Y}^{*}}\right)
$$

where $\mathrm{Y}^{*}$ is the trend rate of output, $\in$ is the sensitivity of the inflation rate to the output gap, $\mathrm{n}$ is the sensitivity of inflation to the changes in unemployment rate, and q represents the Okun's law.

From the above equations of the DAD and DAS, it is clear that last period's output $\left(\mathrm{Y}_{-1}\right)$, changes in autonomous demand including changes in fiscal policy, growth of nominal money supply, growth in nominal exchange rate, foreign inflation and change in expected inflation would shift the DAD curve between inflation rate and output. Similarly, expected inflation rate, the trend level of output $\left(\mathrm{Y}^{*}\right)$ and growth gap from the trend rate of growth would shift the DAS curve. The long-run equilibrium or the state of rest for the system is reached when output (Y) equals trend rate of output $\left(\mathrm{Y}^{*}\right)$ and when inflation rate $(\pi)$ stabilizes and equals the expected inflation $\left(\pi^{\mathrm{e}}\right)$.

In this system, both the curves keep shifting in response to even a slightest external disturbance. However, it is important to note that in this model, inflationary expectations are largely formed on the supply side and changes therein are affecting the demand side. The expected inflation rate underlying a given short-run aggregate supply (SAS) curve is obtained at the trend rate of output $\left(\mathrm{Y}^{*}\right)$. However, the actual rate of inflation is obtained at the intersection of the SAS and DAD. If this intersection does not take place at $\mathrm{Y}^{*}$, both the curves would keep shifting till their intersection occurs at $\mathrm{Y}^{*}$, which would give the long-run equilibrium.

This entire process of adjustment captured by the dynamic demand and supply curves gives rise to the trade-off between inflation and output or employment levels. Thus, the concept of the Sacrifice Ratio is neither a pure supply side nor a pure demand side phenomenon - as generally viewed in the empirical studies on the field (see Kapur and Patra, 2003 for review). As such, the Sacrifice Ratio is a phenomenon on adjustment path consisting of a series of shifting short-run equilibrium from one long-run equilibrium to another long-run equilibrium. Therefore, 
the definition of the Sacrifice Ratio should be in terms of cumulative output losses (or gains) arising out of a series of deliberate policy changes, resulting in a permanent reduction (or increase) in expected inflation rate in the economy. It is not the change in the actual rate of inflation, but in the long-run equilibrium or expected rate of inflation that forms the basis of estimation of the Sacrifice Ratio.

An adverse supply shock is generally not allowed to settle down on its own without policy intervention, but is often accommodated by expansionary policies to minimize output and employment losses at the cost of raising expected inflation permanently. In order to curb and cut these inflationary expectations, contractionary demand policies have to be followed. The Sacrifice Ratio would depend on the nature, dose and effectiveness of such contractionary policies. Broadly speaking, such policies could be either 'cold turkey' type or 'gradualist'. Within each of these, there could be various shades and extents. Sacrifice Ratio for all such alternatives could be a very valuable guiding principle to select the best alternative acceptable politically. However, it implies that there cannot be one uniform Sacrifice Ratio for a given country for all time. While a Sacrifice Ratio requires a macro model, the same macro model can generate several Sacrifice Ratios for a given country under different policy strategies and doses.

Moreover, another important feature of the dynamic macro model is that the trend level of output $\left(\mathrm{Y}^{*}\right)$ is growing with time. In the developed countries, it grows at the rate of 2 to $3 \%$ or less per annum. On the other hand, in India, it is growing at 8 to $9 \%$ per annum, which is substantial to impact the long run equilibrium position in relation to policy changes. The socalled perverse results contrary to the expected ones theoretically from usual macro models in the case of India are, therefore, not surprising as seen from the Figure 1. Similarly, the figure can also be used to show differences in the disinflation policies. If the adverse external supply shock is accommodated by expansionary aggregate demand policies that push the inflation rate further up, central bankers in developed countries have to follow deliberate disinflation policies to bring it back to the normal level soon. On the contrary, in a rapidly growing developing country like India, disinflation can occur on its own if the central bankers merely hold the growth of nominal money supply and nominal depreciation of exchange rate constant. 


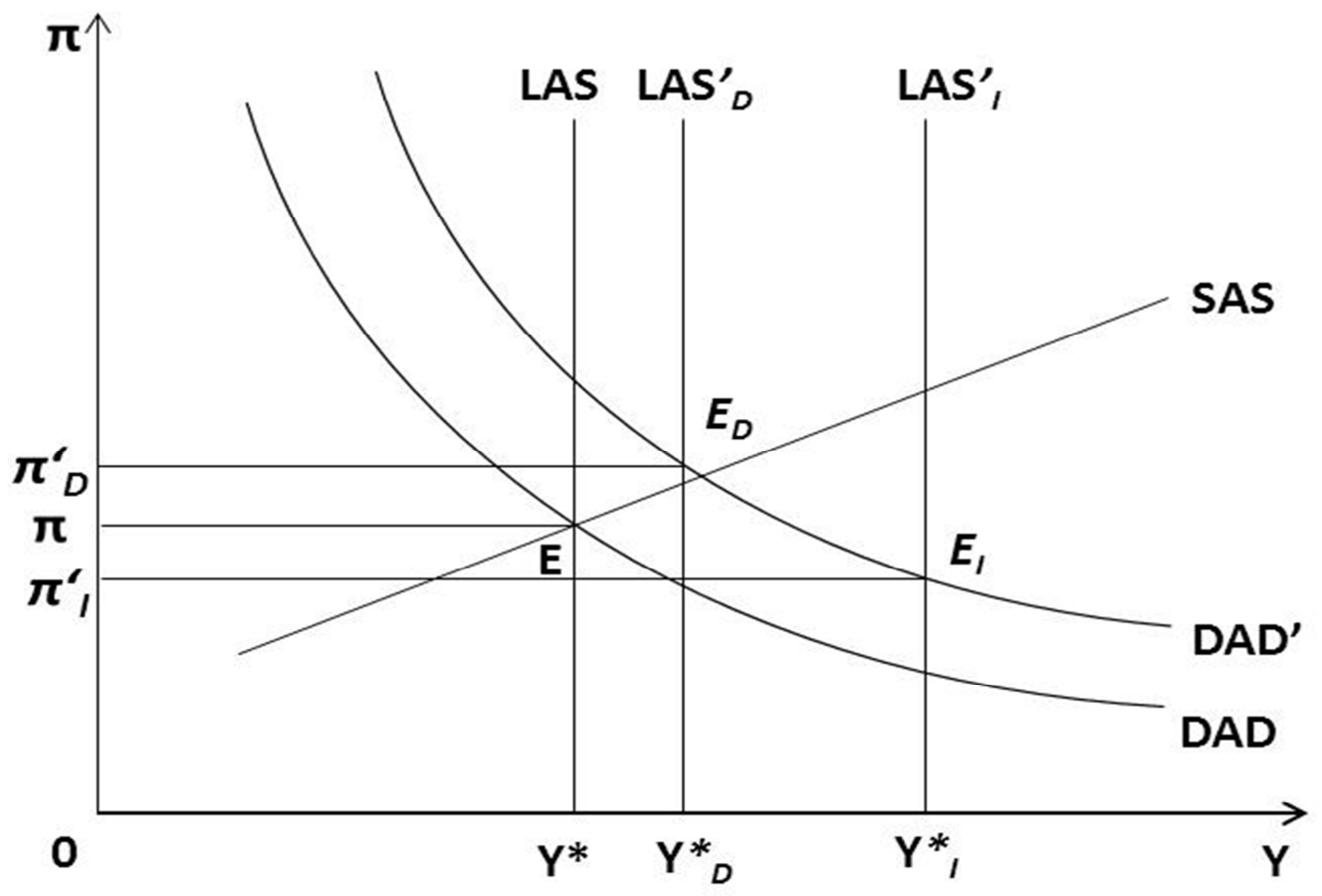

[Figure 1 shows effect of change in the trend rate of output on the effectiveness of the expansionary policy changes of the same magnitude. Intersection of DAD, SAS and LAS at E defines the original long-run equilibrium. In the next year, the trend rate of output shifts by $3 \%$ in developed countries to $Y^{*}$ and by $8 \%$ in India to $Y^{*}$. Simultaneously, expansionary policies of the same magnitude is followed to shift DAD to DAD'. After all adjustments, the new long run equilibrium would settle at $E_{D}$ in developed countries showing rise in both expected inflation and output, and at $E_{I}$ in India showing a fall in expected inflation but rise in output corresponding to the same magnitude of policy dose. In developed countries, disinflation policies would be required to control inflation, but in India, inflation is taken care of by growth of $\left.Y^{*}.\right]$

\section{Methods to Estimate the Sacrifice Ratio}

There are essentially two distinct approaches to estimate the Sacrifice Ratio. One is the direct approach and the other is the regression based approach. In the direct approach, the deliberate disinflation policy episodes are identified from the history and then the output losses from the trend rate of output during the given time period are calculated to obtain the Sacrifice Ratio. The famous study by Ball (1994) follows this approach. The main advantage of this 
approach is that it allows variation in the Sacrifice Ratio by disinflation episodes even within the same country over time. Thus, it allows comparison of efficiency and effectiveness of the central monetary authority in disinflating the economy. The prominent disadvantages of the approach are: (a) it does not consider inflation cost of reducing unemployment ${ }^{3}$; (b) any external shocks, particularly the supply shocks are not controlled; (c) it does not control other exogenous variables like fiscal policy changes, foreign inflation, exchange rate depreciation, etc.; and (d) it involves arbitrary decisions about the length of the episodes.

The regression based approach largely focuses on estimating the DAS derived from the Phillips curve. While it avoids all the limitations of the direct approach as argued by Kapur and Patra (2003), it has the limitation of providing a single estimate of the Sacrifice Ratio for a country covering different and often structurally distinct episodes of both disinflation and inflation. Moreover, it arbitrarily specifies the functional form and variables to be included. However, most of the studies taking the route of DAS to obtain an estimate of the Sacrifice Ratio fail to consider effectively the series of short-run equilibria between shifting DAS and DAD curves in the interim adjustment period. Therefore, studies based on the regression approach would invariably suffer from serious errors of measurement, specification of equation and simultaneity bias for estimation.

Andersen and Wascher (1999) estimate the Sacrifice Ratio through DAS function by introducing the growth of nominal income $\left(\mathrm{g}_{\mathrm{YP}}\right)$ as an explanatory variable and taking the last period's inflation rate $\left(\pi_{-1}\right)$ as the expected inflation. Their DAS function is formulated as -

$\pi=\lambda \mathrm{g}_{\mathrm{YP}}+\beta \pi_{-1}+\propto\left(\mathrm{Y}-\mathrm{Y}^{*}\right)_{-1}+\mu \mathrm{S}$

where S represents exogenous supply shock variables. This is an unconstrained equation providing three different calculations of the Sacrifice Ratio. If a constrained version of (3) is taken by imposing the restrictions: (i) $\alpha=\lambda$; and (ii) $\beta=(1-\lambda)$, then we get a unique estimate of the Sacrifice Ratio as $(1-\lambda) / \lambda$.

\footnotetext{
${ }^{3}$ The Sacrifice Ratio as discussed earlier should be defined both ways: (1) Cumulative output loss to achieve 1 percentage point reduction in inflation rate; and (2) Cumulative output gain to accompany 1 percentage point increase in inflation rate. The latter refers to the inflation cost of reducing unemployment.
} 
Chand (1997) has used another method based on regressions but independent of the DAS function to calculate the Sacrifice Ratio. This is based on the definition of the nominal income. Nominal Income $=$ Y.P

$\Rightarrow \mathrm{g}_{\mathrm{YP}}=\mathrm{g}_{\mathrm{Y}}+\pi$

$\Rightarrow \mathrm{g}_{\mathrm{YP}}=\left(\mathrm{g}_{\mathrm{Y}}-\mathrm{g}_{\mathrm{Y}^{*}}\right)+\left(\pi-\pi_{-1}\right)+\left(\mathrm{g}_{\mathrm{Y}^{*}}+\pi_{-1}\right)$

$=>\left(\mathrm{g}_{\mathrm{Y}}-\mathrm{g}_{\mathrm{Y}^{*}}\right)+\left(\pi-\pi_{-1}\right)=\mathrm{g}_{\mathrm{YP}}-\left(\mathrm{g}_{\mathrm{Y}^{*}}+\pi_{-1}\right)$

Let us define the Sacrifice Ratio as $\left(\mathrm{g}_{\mathrm{Y}}-\mathrm{g}_{\mathrm{Y}^{*}}\right) /\left(\pi-\pi_{-1}\right)=(1-\mathrm{a}) / \mathrm{a}$

Then, $(1-\mathrm{a})\left(\pi-\pi_{-1}\right)=\mathrm{a}\left(\mathrm{g}_{\mathrm{Y}}-\mathrm{g}_{\mathrm{Y}^{*}}\right)$

$=>\left(\pi-\pi_{-1}\right)=\mathrm{a}\left(\mathrm{g}_{\mathrm{Y}}-\mathrm{g}_{\mathrm{Y}^{*}}+\pi-\pi_{-1}\right)$

$=>\left(\pi-\pi_{-1}\right)=\mathrm{a}\left[\mathrm{g}_{\mathrm{YP}}-\left(\mathrm{g}_{\mathrm{Y}^{*}}+\pi_{-1}\right)\right]$

Replacing (5) in (4), we get,

$\left(\mathrm{g}_{\mathrm{Y}}-\mathrm{g}_{\mathrm{Y}^{*}}\right)=(1-\mathrm{a})\left[\mathrm{g}_{\mathrm{YP}}-\left(\mathrm{g}_{\mathrm{Y}^{*}}+\pi_{-1}\right)\right]$

Either equation (5) or equation (6) can be used to estimate the Sacrifice Ratio as defined above. However, if we estimate both the equations (5) and (6) independently, we can check the internal consistency also. However, it may be noted that this method suggested by Chand (1997) does not estimate the correct Sacrifice Ratio because it measures the sacrifice of the growth of output compared to the trend rate of growth of output in order to reduce the current inflation rate by 1 percentage point.

\section{Sacrifice Ratio in India}

Since time series data on unemployment rate is not available in India, we can examine only the inflation-output trade-off. For this purpose, we consider the period of the last 32 yearsfrom 1980-81 to 2011-12. We need to examine the data on inflation, growth in broad money (M3) and fiscal deficit as a percentage of GDP over the period to identify episodes of deliberate disinflation and inflation in recent years. Although it is alleged by Kapur and Patra (2003) that in such a direct approach, the choice about the length of the episodes is arbitrary, actually it is often possible to justify the length of the episode from the data only and hence would not be arbitrary. 
Table 1 provides annual rates of inflation, growth of broad money, fiscal deficit and growth of real GDP in India ${ }^{4}$ over the period 1980-81 to 2011-12.

Table 1: Annual Rates of Inflation, Growth of Money Supply, Fiscal Deficit and Growth of Real GDP (in \%)

\begin{tabular}{|c|c|c|c|c|}
\hline Year & $\begin{array}{c}\text { Annual Inflation } \\
\text { Rate based on GDP } \\
\text { Deflator }(\%)\end{array}$ & $\begin{array}{c}\text { Annual Growth Rate of } \\
\text { M3 (\%) }\end{array}$ & $\begin{array}{l}\text { Combined Fiscal } \\
\text { Deficit ( } \% \text { of GDP) }\end{array}$ & $\begin{array}{c}\text { Annual Growth } \\
\text { Rate of Real GDP } \\
(\%)\end{array}$ \\
\hline $1980-81$ & 11.51 & 18.10 & 6.79 & 7.17 \\
\hline 1981-82 & 10.85 & 12.51 & 6.00 & 5.63 \\
\hline 1982-83 & 8.54 & 16.62 & 5.70 & 2.92 \\
\hline 1983-84 & 8.45 & 18.23 & 7.00 & 7.85 \\
\hline 1984-85 & 8.02 & 18.96 & 8.60 & 3.96 \\
\hline 1985-86 & 7.28 & 15.99 & 7.70 & 4.16 \\
\hline $1986-87$ & 6.89 & 18.63 & 9.50 & 4.31 \\
\hline $1987-88$ & 9.49 & 15.99 & 8.80 & 3.53 \\
\hline $1988-89$ & 8.33 & 17.79 & 8.20 & 10.16 \\
\hline $1989-90$ & 8.54 & 19.36 & 8.60 & 6.13 \\
\hline 1990-91 & 10.64 & 15.10 & 9.10 & 5.29 \\
\hline 1991-92 & 13.74 & 19.27 & 6.80 & 1.43 \\
\hline 1992-93 & 8.86 & 14.81 & 6.80 & 5.36 \\
\hline 1993-94 & 9.98 & 18.42 & 8.00 & 5.68 \\
\hline 1994-95 & 9.78 & 22.39 & 6.90 & 6.39 \\
\hline $1995-96$ & 9.13 & 13.57 & 6.30 & 7.29 \\
\hline 1996-97 & 7.78 & 16.16 & 6.10 & 7.97 \\
\hline $1997-98$ & 6.62 & 18.01 & 7.00 & 4.30 \\
\hline $1998-99$ & 8.05 & 19.44 & 8.70 & 6.68 \\
\hline 1999-00 & 3.10 & 14.60 & 9.10 & 8.00 \\
\hline $2000-01$ & 3.38 & 16.81 & 9.20 & 4.15 \\
\hline 2001-02 & 3.17 & 14.10 & 9.60 & 5.39 \\
\hline $2002-03$ & 3.73 & 14.66 & 9.30 & 3.88 \\
\hline 2003-04 & 3.76 & 16.75 & 8.30 & 7.97 \\
\hline 2004-05 & 5.71 & 11.97 & 7.20 & 7.05 \\
\hline 2005-06 & 4.22 & 21.10 & 6.50 & 9.48 \\
\hline
\end{tabular}

${ }^{4}$ Inflation is measured here through GDP deflator with the base year 2004-05. Money supply is based on the concept of M3. Fiscal Deficit is the combined deficit of Centre and States. Real GDP is measured at constant 200405 prices. 


\begin{tabular}{|l|l|l|l|l|}
$2006-07$ & 6.42 & 21.72 & 5.10 & 9.57 \\
\hline $2007-08$ & 6.02 & 21.38 & 4.00 & 9.32 \\
\hline $2008-09$ & 8.45 & 19.34 & 8.30 & 6.72 \\
\hline $2009-10$ & 6.07 & 16.85 & 9.30 & 8.59 \\
\hline $2010-11$ & 8.82 & 16.09 & 6.90 & 9.32 \\
\hline $2011-12$ & 8.23 & 13.23 & 8.10 & 6.21 \\
\hline
\end{tabular}

Source: RBI, Handbook Of Statistics on Indian Economy2012-13

We can see from the table that the first episode of deliberate disinflation during this period started in 1980-81 when inflation rate was $11.51 \%$, growth of money supply was $18.10 \%$ and the fiscal deficit was $6.79 \%$. RBI cut the growth of broad money to $12.51 \%$ and government cut the fiscal deficit to $6 \%$ in $1981-82$ as a result of which inflation rate fell to $10.85 \%$. In the next year 1982-83, the government continued with the policy to reduce the fiscal deficit to $5.70 \%$ but RBI relaxed the growth of broad money to $16.62 \%$ - still less than initial $18.10 \%$. The inflation rate further fell to $8.54 \%$. In $1983-84$, the fiscal deficit was increased back to $7 \%$ (marginally higher than the initial level) and the growth of money supply was restored to $18.23 \%$. Inflation rate dropped marginally to $8.45 \%$. Thus, the first episode of deliberate disinflation can be taken as $1980-81$ to $1983-84$, because the growth rate of real GDP also returned from $7.17 \%$ in $1980-81$ to $7.85 \%$ in $1983-84$. If we take the growth of potential output as the average of these two end-points, i.e. $7.51 \%$, we can get the Sacrifice Ratio in this disinflation episode to be 2.11 , implying that the society incurred the cost of $2.11 \%$ of a year's potential output to reduce the inflation rate by 1 percentage point.

The second episode of deliberate disinflation though aided by some favorable supply shocks (RBI 2002a) is during the period 1998-99 to 2003-04. In 1998-99, RBI was also effectively made autonomous from the Central Government. The inflation was high at $8.05 \%$, growth of broad money was at $19.44 \%$ and fiscal deficit was at $8.70 \%$ of GDP. RBI started cutting down the growth rate of money supply and brought it down to $16.75 \%$ in 2003-04. Subsequently, the inflation came down to $3.76 \%$ in 2003-04. This episode presents an opportunistic disinflation policy by RBI because the global factors were initially favorable (RBI 2002a). Again following the same method of taking the average of the end-point growth rates of

\footnotetext{
${ }^{5}$ It may be noted that during this period, RBI was not autonomous from the government.
} 
real GDP as the growth of potential output, the Sacrifice Ratio for this second period turns out to be 1.84 .

The third episode is not an episode of disinflation but deliberate inflationary policies and covers the period from $2004-05$ to $2008-09^{6}$. Inflation was at $5.71 \%$ in $2004-05$ and rose to $8.45 \%$ by $2008-09$. While there was a fiscal tightening, RBI increased the growth of money supply from $11.97 \%$ in $2004-05$ to $19.34 \%$ in 2008-09. During this period of inflation, growth of real GDP increased and reached the peak of $9.5 \%$ in 2006-07. The potential output growth during the period as per the average of the two-end point growth was $6.89 \%$. Therefore, the Sacrifice Ratio during this inflationary episode would be 2.81, implying that by incurring the cost of 1 percentage point of more inflation, the society gains $2.81 \%$ more output that may result in reduced unemployment and hence reduced poverty proportion.

The above discussion clearly brings out that the direct approach for calculating the Sacrifice Ratio results in the ratio differing with episodes. Moreover, inflationary episodes can also be identified with the deliberate easy monetary policy and the Sacrifice Ratio in such cases can also be calculated and meaningfully interpreted for developing countries like India. Finally, the Sacrifice Ratio in India from episode to episode moves in a relatively narrow range of 1.8 to 2.8 and is of credible magnitude compared to whatever international experience and estimates are available (See Kapur \& Patra, 2003, Table 1).

Turning to the regression based approach to estimate the Sacrifice Ratio for India, we must note several concerns raised for such estimates in our discussion in the previous two sections. Estimates based only on the aggregate supply curve may not truly reflect the Sacrifice Ratio because the latter captures the phenomenon on the locus of the short-run equilibria between shifting DAS as well as DAD. Therefore, the variables shifting both DAS and DAD should be considered while estimating the Sacrifice Ratio. The equations considered for the estimation represent the solution of DAS and DAD functions for the short-run equilibrium values of $\pi$ and the percentage output gap. In simplified linear form, these equations would be:

\footnotetext{
${ }^{6}$ Again in this case, the end-point coincides with the global financial crisis, but it would only depress the Sacrifice Ratio marginally.
} 
$\pi=b_{1} \pi_{-1}+b_{2}\left(\pi_{-1}-\pi_{-2}\right)+b_{3} \mathrm{~g}_{M S}+b_{4} \Delta(F D / G D P)+b_{5}\left(Y_{-1}-Y^{*}\right) / Y^{*}+b_{6} \mathrm{~g}_{e}+b_{7} \pi_{u s}+$ $b_{8}\left(g_{Y}-g_{Y^{*}}\right)$

$\left(Y-Y^{*}\right) / Y^{*}=a_{1} \pi_{-1}+a_{2}\left(\pi_{-1}-\pi_{-2}\right)+a_{3} \mathrm{~g}_{M S}+a_{4} \Delta(F D / G D P)+a_{5}\left(Y_{-1}-Y^{*}\right) / Y^{*}+a_{6} \mathrm{~g}_{e}+a_{7}$

$\pi_{u s}+a_{8}\left(g_{Y}-g_{Y^{*}}\right)$

Where, FD is the combined Fiscal Deficit and GDP is at current market prices and the rest of the variables are as defined earlier. Here, we are taking the expected inflation to be the previous year's inflation $\left(\pi_{-1}\right)$ following Anderson \& Wascher (1999). Now, the equations (7) and (8) would closely reflect short-run equilibrium values of $\pi$ and percentage output gap as a function of exogenous variables including growth in money supply. The equations (7) and (8) would provide the Sacrifice Ratio as a ratio of the coefficients of $\mathrm{g}_{M S}$ in the two equations. The short run Sacrifice Ratio is given by $\left(a_{3} / b_{3}\right)$. However, the long-run Sacrifice Ratio is $\left[\left(a_{3} /\left(1-a_{5}\right)\right] /\right.$ $\left[b_{3} /\left(1-b_{1}\right)\right]$.

In order to obtain the estimates of equations (7) and (8), we first need to measure the percentage output gap from the potential output. This is obtained by fitting a log-linear trend to the data. Based on the scatter of real GDP, we have considered trend-breaks at 1991-92 and 2003-04 in the series and obtained the following estimate of the spliced regression on LnY:

$\widehat{\operatorname{LnY}}_{t}=13.54+0.0500 t+0.0084 D_{1}(t-12)+0.0227 D_{2}(t-24) \ldots \ldots \ldots \ldots(9)^{7}$

(t-values) (1606) (50.13) (5.20) (10.94)

Adjusted R-squared= 0.9993; Residual standard error=0.0146 on 28 degrees of freedom; All the parameter estimates are statistically significant at $1 \%$ level.

Where $\mathrm{t}=12$ for year 1991-92; and $\mathrm{t}=24$ for year 2003-04. $\mathrm{D}_{1}$ and $\mathrm{D}_{2}$ are dummy variables such that -

$\mathrm{D}_{1}= \begin{cases}0, & 1 \leq t \leq 11 \\ 1, & 12 \leq t \leq 32\end{cases}$

$\mathrm{D}_{2}= \begin{cases}0, & 1 \leq t \leq 23 \\ 1, & 24 \leq t \leq 32\end{cases}$

From equation (9), we get the estimate of the trend level of output $\left(Y_{t}^{*}\right)$ and hence the output gap $=\left(Y_{t}-Y_{t}^{*}\right) / Y_{t}^{*}$.

${ }^{7}$ It is interesting to see that this trend equation (9) implies annual compound growth of 5.12\% during $1980-81$ to 1991-92; 6.01\% during 1991-92 to 2003-04; and 8.44\% during 2003-04 to 2011-12. There has been a continual and substantial acceleration in growth of real GDP in India. 
Now, we turn to the estimates of equations (7) and (8) above. Table 2 presents these estimates.

Table 2: Estimates of Equations (7) and (8) for India, 1980-81 to 2011-12

\begin{tabular}{|c|c|c|c|c|c|c|}
\hline \multirow[t]{2}{*}{ Variables } & \multicolumn{3}{|c|}{ Equation (7) on $\pi$} & \multicolumn{3}{|c|}{ Equation (8) on $\left(Y-Y^{*}\right) / Y^{*}$} \\
\hline & Coefficient & t-value & p-value & Coefficient & t-value & p-value \\
\hline$\pi_{-1}$ & $0.5926 * *$ & 3.822 & 0.000 & -0.0748 & -0.804 & 0.429 \\
\hline$\pi_{-1}-\pi_{-2}$ & -0.1414 & -1.237 & 0.228 & -0.0061 & -0.089 & 0.930 \\
\hline $\mathrm{g}_{M S}$ & 0.1045 & 1.221 & 0.234 & $0.1529 * *$ & 2.979 & 0.007 \\
\hline$\Delta(F D / G D P)$ & -0.2135 & -0.900 & 0.377 & 0.0514 & 0.362 & 0.721 \\
\hline$\left(Y_{-1}-Y^{*}\right) / Y^{*}$ & -0.0537 & -0.261 & 0.796 & $0.3998 * *$ & 3.238 & 0.004 \\
\hline$\pi_{t}^{u s}$ & 0.1888 & 0.949 & 0.352 & 0.0902 & 0.756 & 0.457 \\
\hline$g_{e}$ & 0.0578 & 1.211 & 0.238 & 0.0070 & 0.245 & 0.808 \\
\hline$g_{Y}-g_{Y^{*}}$ & -0.1371 & -0.719 & 0.479 & $0.5853 * *$ & 5.115 & 0.000 \\
\hline Adj. R-square & \multicolumn{3}{|c|}{$0.954 * *$} & \multicolumn{3}{|c|}{$0.424 * *$} \\
\hline Res. Std. Error & \multicolumn{3}{|c|}{1.722 on $24 \mathrm{DF}$} & \multicolumn{3}{|c|}{1.033 on $24 \mathrm{DF}$} \\
\hline
\end{tabular}

Note: ** significantly different from zero at $1 \%$ level.

It can be seen from Table 2 that several variables in the two equations are statistically not significant and the corresponding t-values are less than unity. However, the overall fit of the regression is good in both the cases. It is, therefore, possible to get a better fit in terms of adjusted $\mathrm{R}^{2}$ by dropping insignificant variables one by one in the step-wise regression. Finally, the acceptable regression estimates that emerged are presented in Table 3.

Table 3: Estimates of the Best Fit of Equations (7) and (8) for India, 1980-81 to 2011-12

\begin{tabular}{|c|c|c|c|c|c|c|}
\hline \multirow[t]{2}{*}{ Variables } & \multicolumn{3}{|c|}{ Equation (7) on $\pi$} & \multicolumn{3}{|c|}{ Equation $(8)$ on $\left(Y-Y^{*}\right) / Y^{*}$} \\
\hline & Coefficient & t-value & $\mathrm{p}$-value & Coefficient & t-value & $\mathrm{p}$-value \\
\hline$\pi_{-1}$ & $0.5779 * *$ & 4.082 & 0.000 & -- & $\begin{array}{ll}- \\
-\end{array}$ & -- \\
\hline$\pi_{-1}-\pi_{-2}$ & -0.1464 & -1.324 & 0.196 & -- & -- & -- \\
\hline $\mathrm{g}_{M S}$ & $0.1247 * * *$ & 2.462 & 0.020 & $0.1464 * *$ & 4.106 & 0.000 \\
\hline$\Delta(F D / G D P)$ & -- & -- & -- & -- & -- & -- \\
\hline$\left(Y_{-1}-Y^{*}\right) / Y^{*}$ & -- & -- & -- & $0.4258 * *$ & 4.207 & 0.000 \\
\hline$\pi_{t}^{u s}$ & 0.2096 & 1.129 & 0.269 & -- & -- & -- \\
\hline$g_{e}$ & 0.0584 & 1.513 & 0.142 & -- & -- & -- \\
\hline$g_{Y}-g_{Y^{*}}$ & -- & -- & -- & $0.5707 * *$ & 5.555 & 0.000 \\
\hline Adj. R-square & \multicolumn{3}{|c|}{$0.957 * *$} & \multicolumn{3}{|c|}{$0.503^{* *}$} \\
\hline Res. Std. Error & \multicolumn{3}{|c|}{1.667 on $27 \mathrm{DF}$} & \multicolumn{3}{|c|}{0.9596 on $29 \mathrm{DF}$} \\
\hline
\end{tabular}

Note: ** significant at $1 \%$ level; *** significant at $5 \%$ level. 
From the estimates of the coefficients of $\mathrm{g}_{\mathrm{MS}}$ given in Table 3, we can calculate the Sacrifice Ratio for India since both the coefficients are statistically significant. The estimate for the Sacrifice Ratio turns out to be $(0.1464 / 0.1247)=1.2$ in the short-run; and [0.1464/0.5742) / $(0.1247 / 0.4221)]=0.9$ in the long-run ${ }^{8}$. The short-run ratio is higher than the long-run ratio because the ratio is calculated for one percentage point reduction in the growth of money supply (other things remaining the same). As time passes, expected inflation falls leading to positive effect on output and negative effect on inflation. Therefore, the Sacrifice Ratio in the long-run is likely to be lower than in the short-run for the same initial reduction in growth of money supply.

The regression approach estimates a constant and unique Sacrifice Ratio for an economy as an average applicable over the entire period under consideration. On the other hand, the direct approach allows the Sacrifice Ratio to vary across different episodes of disinflation and inflation. However, the regression approach allows us to estimate the Sacrifice Ratio for the monetary policy interventions by holding all other relevant factors constant. The regression approach is, therefore, likely to provide more conservative estimates of the Ratio. In case, our interest is to get separate estimates of the Ratio for episodes of disinflation and inflation, the direct approach is the only alternative. For India, it shows the ratio varying by episodes of disinflation from 1.8 to 2.1; and for the episode of inflation to be 2.8 .

${ }^{8}$ As an alternative method to estimate the Sacrifice Ratio through the regression approach, we may consider equations (5) \& (6) above following Chand (1997). The estimates of the two equations are:

$\left(\pi-\pi_{-1}\right)=0.5812\left[\mathrm{~g}_{\mathrm{YP}}-\left(\pi_{-1}+\mathrm{g}_{\mathrm{Y}^{*}}\right)\right.$

t-value: $\quad(4.79) ; \quad$ Adj. R-square $=0.4065$

$\mathrm{g}_{\mathrm{Y}}-\mathrm{g}_{\mathrm{Y}}=0.4188\left[\mathrm{~g}_{\mathrm{yp}}-\left(\pi_{-1}+\mathrm{g}_{\mathrm{y}}\right)\right.$

t-value: $\quad(3.45) ; \quad$ Adj. R-square $=0.2541$

Both these estimates are significant at $1 \%$ level. Moreover, since both the estimated coefficients add up to one, the requirement of internal consistency is met. The Sacrifice Ratio in this framework works out to be $(0.4188 / 0.5812)=0.72$. However, it should be noted that this estimate should be interpreted to say that the difference of actual growth of output from the growth of potential output would fall by 0.72 percentage points when actual inflation declines by 1 percentage point. This estimate is close to the one obtained above for the long-run (0.86), but since no other factor is held constant, it cannot be considered only the result of any deliberate monetary policy. 


\section{V. $\quad$ Cost of Inflation in India}

It is necessary to consider the cost of inflation in India in view of the Sacrifice Ratio estimates. Thus, reducing the long-run inflation say, from $8 \%$ to $5 \%$, would entail the social cost of sacrificing $5.4 \%$ to $6.3 \%$ of potential output as per our estimates in the previous section.

By now it is very well accepted that long term anticipated inflation has hardly any serious cost on the society and that unanticipated inflation largely has distributional costs in the society (Dornbusch, Fischer \& Startz, 2012; Mankiw, 2010). Barro (1995) and Fischer (1993) argue that so long as inflation is moderate, say less than $10 \%$ p.a., it does not hurt the long-term growth of the economy. On the other hand, Chopra (1988); Motley (1994); Paul et al. (1997); and Chaturvedi et al. (2009) find negative impact of inflation on growth in a cross-country and Indian context. Chaturvedi et al. (2009) provide the latest evidence and their study period is 1989 to 2003. It, therefore, requires examining this issue with latest data for India. This is because if reducing inflation rate from say $8 \%$ to $5 \%$ does not have any positive impact on the long-term growth, it may not be worth sacrificing about $6 \%$ of potential output to achieve such a reduction. If, on the other hand, it raises the long-term growth substantially, it may be worth undertaking reduction of inflation.

In order to examine this relationship, we have fitted the log-linear trend on the GDP deflator from which we derive the inflation rate. By observing the scatter, we identified two trend-break points: 1998-99 when RBI was given effective autonomy; and 2004-05 when UPA-1 came to power with an explicit commitment to double agricultural credit every three years. The fitted regression equation is -

$\operatorname{Ln}($ GDPdef. $)=2.7463+0.0867 \mathrm{t}-0.0560 \mathrm{D}_{1}(\mathrm{t}-19)+0.0376 \mathrm{D}_{2}(\mathrm{t}-25)$

t-values: $\quad(286.2) \quad(108.7) \quad(-18.94)$

Adjusted R-square $=0.999$; Residual Standard Error $=0.0206$ for 28 Degrees of Freedom.

$\mathrm{D}_{1} \& \mathrm{D}_{2}$ are dummy variables such that -

$\mathrm{D}_{1}=\left\{\begin{array}{l}0,1 \leq t \leq 18 \\ 1,19 \leq t \leq 32\end{array}\right.$ 
$\mathrm{D}_{2}= \begin{cases}0, & 1 \leq t \leq 24 \\ 1, & 25 \leq t \leq 32\end{cases}$

All parameters are significant at $0.1 \%$ level.

Thus, there are three distinct phases of inflation experience in the country: (i) 1980-81 to 1998-99, when the trend rate of inflation was $9.06 \%$ p.a.; (ii) $1998-99$ to $2004-05$, when the trend rate of inflation was $3.02 \%$ p.a. and (iii) $2004-05$ to 2011-12, when the trend rate of inflation was $7.07 \%$ p.a. From phase (i) to (ii), there was a conscious effort to bring down the long-run inflation in the economy by almost 6 percentage points. It can be seen from the Table 1 above that RBI after becoming autonomous in 1998-99 attempted to cut the growth of money supply substantially to achieve this, though its efforts were compounded and facilitated by global factors (RBI, 2002a). On the contrary, from phase (ii) to (iii), there was a conscious effort to raise the inflation rate in the economy by almost 4 percentage points through systematic efforts to raise the growth of money supply (see Table 1 above). In order to examine the broad effects of such sharp long-term deflation and inflation on the output growth in the economy, we also fitted loglinear trend on GDP at 2004-05 prices taking the same trend-break points as in the case of GDP deflator. The fitted regression equation is -

$\operatorname{Ln} \mathrm{Y}_{\mathrm{t}}=13.52+0.0533 \mathrm{t}+0.0102 \mathrm{D}_{1}(\mathrm{t}-19)+0.0192 \mathrm{D}_{2}(\mathrm{t}-25)$

t-values: (1556) (73.8)

Adjusted R-square $=0.9989$; Residual Standard Error $=0.0187$ for 28 Degrees of Freedom .

$D_{1}$ and $D_{2}$ are dummy variables with same definition as in equation (10).

All parameters are significant at $0.1 \%$ level.

These estimates show that during the same three phases identified above on the basis of inflationary trends, the trend growth of output turned out to be: (i) $5.47 \%$ p.a. during $1980-81$ to $1998-99$; (ii) $6.55 \%$ p.a. during $1998-99$ to $2004-05$; and (iii) $8.61 \%$ p.a. during 2004-05 to 201112. Thus, the output growth consistently and continually accelerated across the three phases while the trend rate of inflation fell sharply between phases (i) and (ii); and sharply increased between phases (ii) and (iii). Figure 2 provides the graphs of the fitted log-linear trend rates and actual annual growth for both GDP deflator and real GDP by years. 
If we consider the period only up to 2004-05 as was done by Chaturvedi et al. (2009), it would appear that inflation and growth of output are negatively related. In other words, a reduction of inflation by about 6 percentage points leads to an increase of about 1 percentage point in longterm output growth, or a reduction of 1 percentage point in trend rate of inflation would lead to about 0.18 percentage points increase in the long-term annual growth rate.

Figure 2: Fitted Trend Rates and Actual Annual Inflation Rates and Growth Rates in India

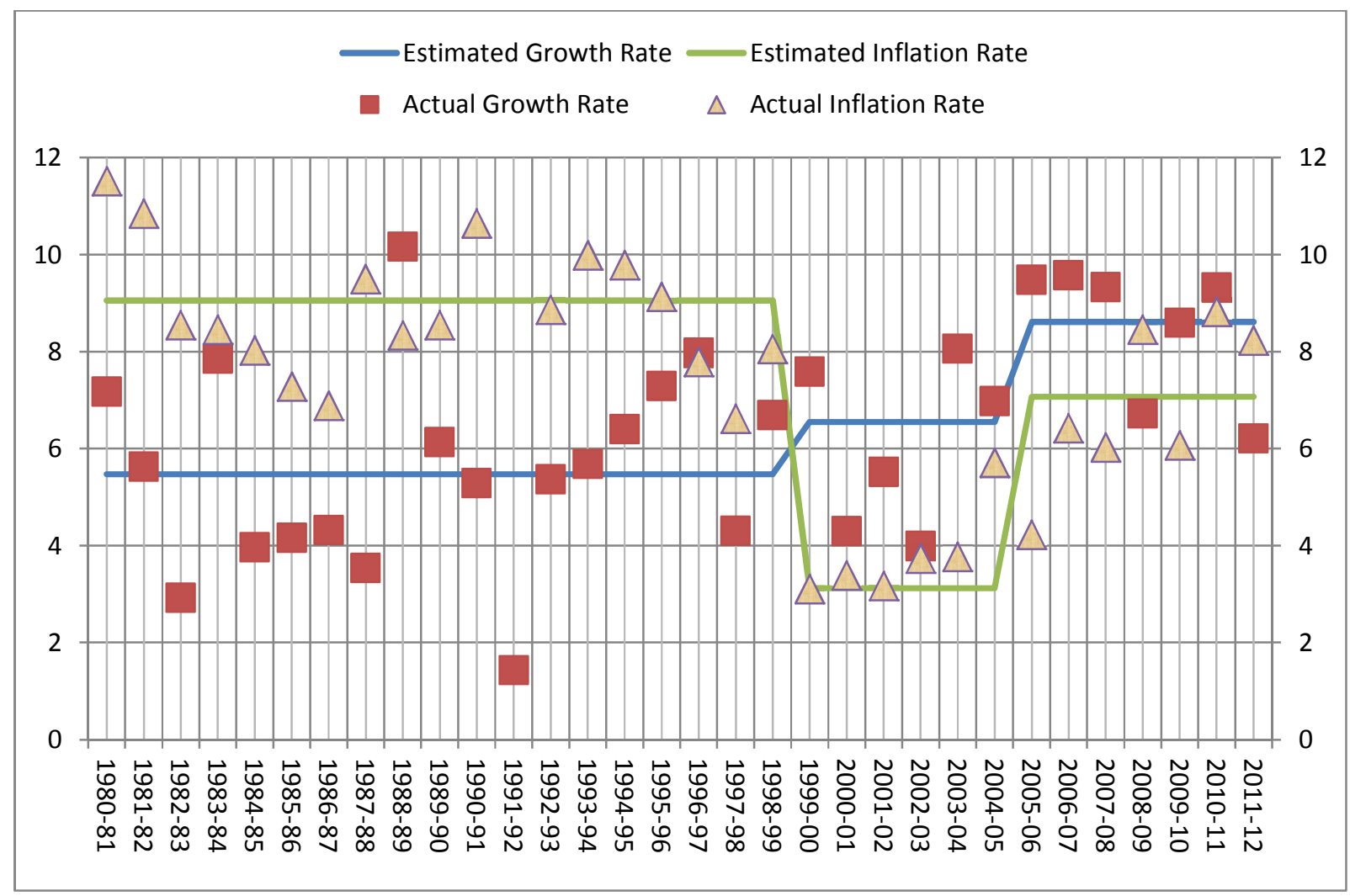

However, after 2004-05, the experience in India tells a different story. An increase of about 4 percentage points in trend rate of inflation between phases (ii) and (iii) is accompanied by an increase of more than 2 percentage points in the long-term growth rate of output. Thus, inflation and growth of output are positively related. In this case, there are no particular benefits of attempting to reduce trend rate of inflation. On the contrary, raising the trend rate of inflation by 1 percentage point may result in increasing the long-term growth by 0.51 percentage point. Such contradictory evidences would obviously make the regression results covering the entire period less reliable and even statistically less significant. 
In this context, the finding of Dholakia \& Sapre (2012) about the length of period considered by people to form price expectations in the country become very relevant to examine costs or benefits of changes in the long-term inflation trend in terms of output growth. Dholakia \& Sapre (2012) find that people consider the experience of last four years to form inflationary expectations in India. Therefore, the permanent benefits of reducing long-term inflation rate would be felt only after 4-5 years. Thus, reduction of trend rate of inflation by about 6 percentage points during 1998-99 to 2003-04 would show the real impact on the long-term growth of output after 2004-05 and continue up to 2008-09, because there is an upward shift in the trend rate of inflation around 2004-05. A sharp increase in trend rate of inflation after 200405 similarly would show its negative impact on growth after 4-5 years, i.e. after 2008-09 or 2009-10. If we examine the growth experience in recent years, adjust for the external and exogenous factors and relate it to the inflation rate before $4-5$ years, we would corroborate the substantial negative influence of inflation on growth ${ }^{9}$.

\section{Concluding Remarks}

Thus, the cost of high inflation is the sacrifice of substantial growth in the long-term; and the benefit of disinflation is a sizeable gain in the long-term growth in the economy. However, disinflation is not costless as we have seen through the Sacrifice Ratio of about 0.9 to 2.1 in the short to intermediate period. On the other hand, the long-run gain in the growth rate per percentage point reduction in inflation rate is only 0.5 . If, therefore, a 3 percentage point reduction in trend rate of inflation is targeted, it would start positively impacting the growth after about 4-5 years and would take nearly 2 to 4 additional years to recover the cost of achieving it without discounting for the society. It is a moot question whether the political priorities and commitments would remain the same over such a long period. If not, it may take longer to recover the cost of disinflation. RBI needs to seriously consider achieving disinflation at a relatively high cost compared to the gain from it with respect to the time element involved.

\footnotetext{
${ }^{9}$ This is because Chaturvedi et al. (2009) have conclusively established that the relationship between inflation and growth is not bi-directional, but uni-directional- from inflation to growth only. This is particularly true for Asian countries.
} 
On the other hand, raising the trend inflation marginally appears to be politically a good option, because the gains are immediate in terms of higher growth, more employment and poverty reduction, and the costs in terms of lower long-term growth are in the future, perhaps for the next government to face. On account of data limitations, strong evidence on the hypothesis of growth of output leading to expansion in employment leading to poverty reduction in India is not available. However, output elasticity of employment and employment elasticity of poverty proportion can be calculated from the readily available data from the NSS Surveys on employment -unemployment situation and on consumer expenditures undertaken in 1993-94 (NSS 43 ${ }^{\text {rd }}$ Round) and 2011-12 (NSS 63 ${ }^{\text {rd }}$ Round). The output elasticity of employment works out to +0.1882 ; employment elasticity of poverty proportion works out to (-) 3.3643 ; and output elasticity of poverty proportion works out to (-) $0.6331^{10}$. These figures do provide broad support to the hypothesized relationship between higher growth and more employment and poverty reduction in India. It is then possible to argue a case for an inflationary policy through the Sacrifice Ratio to incur permanent cost of inflation to gain temporarily in terms of employment creation and poverty reduction. Thus, pure cost-benefit analysis of disinflationary versus inflationary policies may favor the latter over the former depending on the magnitudes of the Sacrifice Ratio and the long-term costs / benefits of disinflation / inflation in an economy.

\section{References:}

Andersen, P. S. and W. L. Wascher (1999). 'Sacrifice ratios and the conduct of monetary policy in conditions of low inflation', BIS Working Papers, 82, Bank for International Settlements.

Ball, L. N. (1994). 'What Determines the Sacrifice Ratio?' in N.Gregory Mankiw (ed.) Monetary Policy, University of Chicago Press, pp.155 - 193.

Barro, R. (1995). 'Inflation and Economic Growth', NBER Working Papers 5326, National Bureau of Economic Research, Inc.

Chand, S.K. (1997), Nominal Income and the Inflation-Growth Divide, IMF Working Paper WP/97/147.

\footnotetext{
${ }^{10}$ All these are arc elasticity estimates calculated from two end points.
} 
Chaturvedi, V., B. Kumar and R. H. Dholakia (2009). 'Inter-relationship between Economic Growth, Savings and Inflation in Asia', Journal of International Economic Studies, No. 23, March, pp. 1-22.

Chopra, S. (1988). Inflation, Household Savings and Economic Growth, Ph.D. thesis, M.S. University of Baroda, India.

Dholakia, R. H. (1990). 'Extended Phillips curve for the Indian economy', Indian Economic Journal, 38 (1), pp. 69-78.

Dholakia, R. H. and A. Sapre (2012). 'Speed of Adjustment and Inflation- Unemployment Tradeoff in Developing Countries - Case of India', Journal of Quantitative Economics, 10(1), pp. 1-16.

Dornbusch, R. and S. Fischer (1990). 'Macroeconomics', 5th Edition, New York, McGraw Hill (India) Pvt. Ltd.

Dornbusch, R., S. Fischer and R. Startz (2012). 'Macroeconomics', 10th Edition, New Delhi, Mcgraw Hill Education (India) Pvt. Ltd.

Fischer, S. (1993). 'The role of macroeconomic factors in growth', Journal of Monetary Economics, 32 (3), pp. 485-512.

Kapur M. and M. D. Patra (2003). 'The Price of Low Inflation', RBI Publications, 33952, January.

Mankiw, N. G. (2010). 'Macroeconomics', 7th Edition, New York, Worth Publishers.

Motley, B. (1994). 'Growth and Inflation: A Cross-Country Study', CEPR Publication No. 395, Centre for Economic Policy Research, Stanford University, March.

Paul, S., C. Kearney and K. Chowdhury (1997). 'Inflation and economic growth: a multi-country empirical analysis', Applied Economics, 29(10), pp. 1387-1401.

Reserve Bank of India (2002). Report on Currency and Finance, 2000-01.

- (2002a), Annual Report, 2001-02.

_ (2013), Handbook of Statistics on Indian Economy 2012-13. 